\title{
INFLUENCE OF ROOTSTOCKS ON PLUM PRODUCTIVITY IN DIFFERENT GROWING REGIONS
}

\author{
Dzintra Dēḳena ${ }^{1}$, Alena V. Poukh², Kersti Kahu ${ }^{3}$, Valda Laugale ${ }^{*}$, and Inga Alsinaa ${ }^{4}$ \\ ${ }^{1}$ Institute of Horticulture, Latvia University of Agriculture, Graudu iela 1, Dobeles nov., Krimūnu pag., LV-3701, LATVIA \\ ${ }^{2}$ Brest Regional Agricultural Experimental Station of the National Academy of Science of Belarus, Urbanovich str. 5, Pruzani, \\ Brest reg., 225133, BELARUS \\ ${ }^{3}$ Polli Horticultural Research Centre of Estonian University of Life Sciences, Karksi-Nuia 69101, Viljandimaa, ESTONIA \\ ${ }^{4}$ Latvia University of Agriculture, Lielā iela 2, Jelgava, LV-3001, LATVIA \\ Corresponding author, dzintra.dekena@puresdis.lv
}

Communicated by Edīte Kaufmane

\begin{abstract}
Proper selection of rootstock that is adapted to local growing conditions and climate is one of the most important preconditions for obtaining high yield in intensive plum orchards. The aim of the investigation was to evaluate the influence of different rootstocks on the productivity of two plum cultivars: 'Kubanskaya Kometa' (Prunus rossica. Erem.) and 'Victoria' (P. domestica L.) in different climatic conditions. The following sixteen rootstocks known in Europe were used in the trial: eight vegetatively propagated ('St. Julien A', 'Brompton', 'Ackermann', 'Pixy', 'GF 8/1', 'G 5/22', 'GF 655/2', 'Hamyra') and eight generatively propagated ('St. Julien INRA2', 'St. Julien d'Orleans', 'St. Julien Noir', 'Brompton', 'Wangenheims Zwetsche', 'St. Julien Wädenswil', 'Myrobalan', P. cerasifera var. divaricata). The evaluation was made in experimental orchards in Latvia, Estonia and Belarus. Orchards were established in spring 2001. Trees were planted at spacing $3 \times 5 \mathrm{~m}$ in four replications, three trees per plot. The data obtained in years 2008-2015 are presented. The yield was influenced by rootstock and differed between years, growing regions and cultivars. The meteorological conditions during wintering period had significant influence on yield for trees on all evaluated rootstocks.
\end{abstract}

Key words: Prunus domestica, Prunus cerasifera, cultivar, yield, meteorological conditions, Latvia, Estonia, Belarus.

In practice the correct choice of rootstock is one of the most important preconditions for establishing productive and sustainable orchards. The lack of appropriate rootstocks is one of the reasons that prevents wide introduction of plum orchards in all of North East Europe. The compatibility of rootstock and cultivar is very important also, as it determines tree productivity and its forming parameters. It has been reported that tree longevity, resistance to unfavourable weather conditions, canopy size, start of production and production intensity depend not only on rootstock but also on its compatibility with the grafted cultivar (Wertheim, 1998).

In Latvia and Estonia, the most popular rootstock for plums is Caucasian plum (Prunus cerasifera Ehrh. var. divaricata C. K. Schreid). This rootstock does not ensure the requirements of intensive orchards due to its excessive vigour (Grzyb et al. 1998; Rozpara et al. 2010), and incompatibility with some Europeans cultivars (Lepsis et al. 2004). At
Pūre Horticultural Research Centre, low healthiness of trees grafted on Caucasus plum as rootstock was observed (Lepsis et al., 2008).

In European countries, rootstocks such as 'Myrobalan', 'St. Julien A', 'Wangenheims Zwetsche' (Rozpara and Grzyb, 2007) and dwarf rootstock 'Pixy' (Sosna, 2002) are widely grown and investigated. The plum rootstocks have been relatively much studied in Europe, while they are less studied in Latvia. 'St. Julien A', 'GF 655/2', 'Myruni', 'SVG 11-19' have been evaluated in Dobele (Kaufmane et. al., 2007). In recent years, more investigations have been conducted on 'Wangenheims Zwetsche' rootstock (Grāvīte and Kaufmane, 2013).

Climatic conditions during wintering can be very changeable in Latvia, Estonia, and Belarus. Climate significantly influences tree healthiness and productivity. Especially the winter hardiness of flower buds is very important for obtaining high yield. Low temperatures are very critical at the 
end of winter when the tree dormancy period is over, and can significantly reduce or even destroy plum yield (Proebsting, 1982). Also changes in the active frost period in the middle of winter can cause strong tree damage (Jänes and Kahu, 2008).

Cultivars 'Victoria' (Prunus domestica L.) and hybrid plum 'Kubanskaya Kometa' (Prunus rossica. Erem.) are widely grown in Latvia and therefore they were included in the investigation.

The aim of the investigation was to evaluate the influence of two cultivars and 16 different rootstocks on the plum productivity in the period 2008-2014.

Plant material. Plum cultivars 'Victoria' and 'Kubanskaya Kometa' were grafted on eight different clonal rootstocks: 'St. Julien A', 'Brompton', 'Ackermann', 'Pixy', 'GF8/1', 'G5/22', 'GF655/2' and 'Hamyra', and eight seedling rootstocks: 'St. Julien INRA 2', 'St. Julien d'Orleans', 'St. Julien Noir', 'Brompton', 'Wangenheims Zwetsche', 'St. Julien Wädenswil', 'Myrobalan' and Prunus cerasifera var. divaricata. The study was performed at the Institute of Horticulture in Pūre, Latvia, at the Polli Horticultural Research Centre, Estonia, and at the Brest Regional Agricultural Experimental Station, Belarus. The experimental orchards were established in spring 2001. Plants were planted at spacing $3 \times 5 \mathrm{~m}$, in four replications with three trees per plot. The soil type was loam in Pūre, sandy clay in Polli, and loamy sand in Brest (Poukh, Matveyev, 2011).
Average yield per tree $(\mathrm{kg})$ was analysed during the period 2008-2015. Data were analysed using descriptive statistics and ANOVA. Differences between the means were tested by the least significant difference (LSD) at a $5 \%$ significance level.

Meteorological conditions. Meteorological data were collected at local meteorological stations in all three trial places. Data are presented in Table 1. Significant differences in meteorological parameters were observed among years whereas they did not differ significantly between growing regions. The air temperature fluctuation trend was similar in all three growing regions during winter. The lowest air temperature was observed in January 2009/2010 at Polli when temperature dropped to $-35.3{ }^{\circ} \mathrm{C}$, and $-31.6{ }^{\circ} \mathrm{C}$ at Brest. At Polli, the air temperature dropped below $-30{ }^{\circ} \mathrm{C}$ in February during winters of 2010/2011 and 2011/2012. The winter period of 2010/2011 was especially cold, as frost below $-10{ }^{\circ} \mathrm{C}$ was observed from November to March in all trial locations, and even in March the temperature was $-19{ }^{\circ} \mathrm{C}$ in Brest.

At Pūre, significant damage to flower buds was observed in spring 2010 and 2011, when air temperature dropped to $-3.3{ }^{\circ} \mathrm{C}$ in May, as well in spring of 2014 , when air temperature dropped to $-4.5{ }^{\circ} \mathrm{C}$. It caused high loss of yield. During that period, there were no spring frosts at Brest.

Significant difference in productivity was observed among years for cultivar 'Kubanskaya Kometa' in all growing re-

Table 1

MINIMUM AIR TEMPERATURES IN MONTHS OCTOBER-MAY OF 2008/2009, 2009/2010, 2010/2011, 2011/2012, 2012/2013 AND 2014/2015

\begin{tabular}{|c|c|c|c|c|c|c|c|c|}
\hline Month & Region & $2008 / 2009$ & $2009 / 2010$ & $2010 / 2011$ & $2011 / 2012$ & $2012 / 2013$ & $2013 / 2014$ & $2014 / 2015$ \\
\hline \multirow[t]{2}{*}{ October } & Polli & 2.4 & -4.4 & -4.3 & -0.8 & -5.1 & -4.7 & -0.7 \\
\hline & Pūre & -0.4 & -4.4 & -3.2 & -2.0 & -5.7 & -2.6 & -5.8 \\
\hline \multirow[t]{3}{*}{ November } & Polli & -5.5 & -6.8 & -21.9 & -6.6 & -7.7 & -10.3 & -2.4 \\
\hline & Pūre & -3.3 & -4.7 & -15.2 & -6.2 & -1.1 & -5.9 & -10.0 \\
\hline & Brest & -3.8 & -4.7 & -14.9 & -7.2 & -2.4 & -5.8 & -11.0 \\
\hline \multirow[t]{3}{*}{ December } & Polli & -8.7 & -24.1 & -14.4 & -3.1 & -19.1 & -10.5 & -10.0 \\
\hline & Pūre & -6.1 & -22.7 & -18 & -4.9 & -17.1 & -9.0 & -16.7 \\
\hline & Brest & -10.4 & -23.6 & -14.9 & -5.0 & -21.9 & -7.6 & -13.1 \\
\hline \multirow[t]{3}{*}{ January } & Polli & -15.7 & -35.3 & -22.1 & -21.7 & -27.2 & -19.4 & -12.5 \\
\hline & Pūre & -21.9 & -28.6 & -16.9 & -22.5 & -21.1 & -25.4 & -14.8 \\
\hline & Brest & -25.6 & -31.6 & -16.2 & -23.0 & -23.7 & -21.9 & -17.4 \\
\hline & Pūre & -15.6 & -21.6 & -28.5 & -29.7 & -20.9 & -11.7 & -7.9 \\
\hline & Brest & -17.0 & -15.8 & -20.4 & -30.0 & -14.3 & -15.0 & -12.1 \\
\hline \multirow[t]{3}{*}{ March } & Polli & -11.4 & -18.3 & -15.3 & -19.0 & -24.8 & -3.3 & -4.3 \\
\hline & Pūre & -11.5 & -20.4 & -16.9 & -13.0 & -19.3 & -8.9 & -8.9 \\
\hline & Brest & -11.4 & -12.2 & -19.2 & -7.9 & -15.1 & -3.5 & -7.3 \\
\hline \multirow[t]{3}{*}{ April } & Polli & -6.4 & -4.5 & -3.7 & -8.3 & -3.2 & -0.5 & 1.0 \\
\hline & Pūre & -5.4 & -4.3 & -4.0 & -13.2 & -10.1 & -8.0 & -2.5 \\
\hline & Brest & -3.3 & -1.9 & -0.3 & -4.2 & -5.1 & -5.5 & -2.7 \\
\hline \multirow[t]{3}{*}{ May } & Polli & -2.5 & -2.9 & -2.4 & -1.7 & 7.9 & 2.7 & 6.6 \\
\hline & Pūre & -1.5 & -3.2 & -3.3 & -1.2 & -2.7 & -4.5 & -1.5 \\
\hline & Brest & 0.6 & 2.7 & -1.0 & 3.3 & 3.9 & 0.2 & 1.8 \\
\hline
\end{tabular}


gions. At Pūre and Brest, the highest yield was harvested in 2008, whereas at Polli it was the highest in 2009. The highest flowering intensity was also observed in these years (Dēknena et al., 2013). At Pūre, the highest average yield among years was obtained from trees grafted on 'Brompton' seedlings (16.2 kg per tree), 'GF 8/1' (15.8 kg per tree) and 'Wangenheims Zwetsche' (14.2 kg per tree) (Fig. $1)$. The lowest average yield was harvested from trees on 'Ackerman' (7.9 kg per tree), 'St Julien Noir' and P. cerasifera var. divaricata (8.5 kg per tree) rootstocks. In 2010, 2011, and 2014, the trees on almost all rootstocks did not bear fruits because of flower bud damage during spring frosts.

At Brest, the highest yield was harvested from trees on 'St. Julien INRA 2' and 'Wangenheims Zwetsche' (18.5 kg per tree) rootstocks. Even in 2010, higher yields were harvested at Brest than at Pūre and Polli because trees did not suffer from spring frosts. There were observed also higher minimum temperatures during all wintering periods at Brest compared to those at Pūre and Polli.

At Polli, the yield was significantly lower than at Pūre and Brest $(p=0)$ for cultivar 'Kubanskaya Kometa'. However, significant differences between rootstocks were not observed $(p=0.236)$, which can be explained by more severe meteorological conditions during winter at Polli. Cultivar 'Kubanskaya Kometa' is characterised by good winter hardiness in southern regions of Russia (Eremin and Safarov, 2013), whereas in Latvia and Estonia it is less winter hardy in comparison to European plums (Lepsis et.al., 2008; Jänes and Kahu, 2008). The winter hardiness of this cultivar can be also influenced by thaws during winter, because it belongs to the $P$. cerasifera plum group characterised by a short dormancy period. During the dormancy period. it can withstand even a drop of temperature to $-30{ }^{\circ} \mathrm{C}$, whereas after the dormancy period the resistance to low temperatures sharply decreases, when it can withstand temperature -10 to $-15{ }^{\circ} \mathrm{C}$ only for a short period (Eremin, 1993). The highest average yield was harvested from trees on 'St. Julien d' Orleans' (9.5 kg per tree) and 'Myrobalan' (8.4 kg per tree) rootstocks at Polli. The lowest average yield was obtained from trees grafted on 'St. Julien Wädenswill' (3.1 kg per tree).

The yield for cultivar 'Victoria' significantly differed between growing regions $(p=0)$ and rootstocks used ( $p=$ 0.05). At Pūre and Polli, the highest yield was harvested in 2008, whereas in 2010 at Brest. Low flowering intensity and thereby low yield was observed in 2009 because regeneration pruning was performed during winter 2008/2009. At Pūre, the highest yield was harvested from trees on rootstocks 'Hamyra' (60.7 kg per tree), 'Ackermann' and $P$. cerasifera var. divaricata $(54.8$ and $54.1 \mathrm{~kg}$ per tree, respectively) in 2008 (Fig. 2). These trees gave also the highest average yield. The lowest average yield was harvested from trees grafted on 'G5/22' and 'Pixy' (12.7 and $15.2 \mathrm{~kg}$ per tree, respectively).

At Polli, the highest yield was harvested from trees grafted on 'Ackermann' in 2008 (37.9 kg per tree), while the average yield within years was $22.5 \mathrm{~kg}$ per tree. In 2009, a high

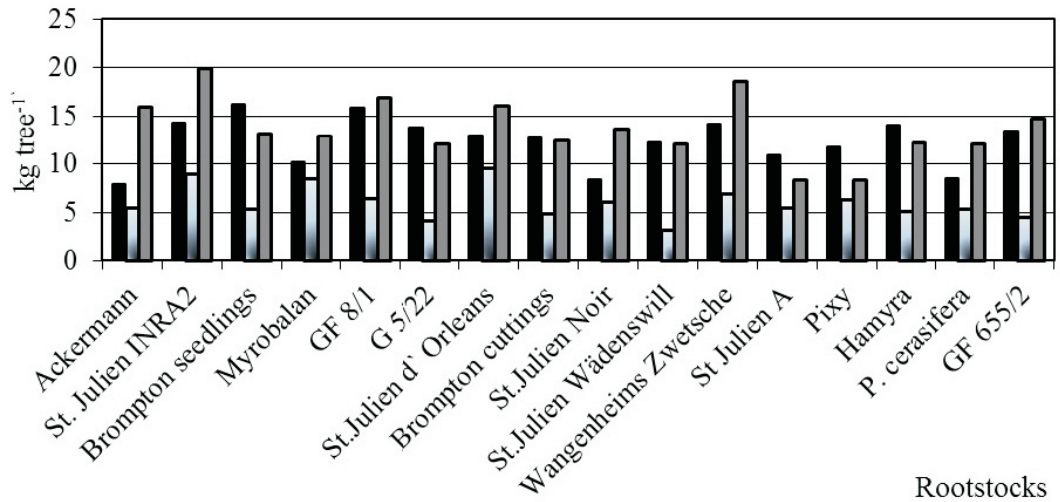

- Pūre $\square$ Polli $\square$ Brest

Fig. 1. Average yield during the period of 2008-2015 for cultivar 'Kubanskaya Kometa' ( $\mathrm{kg}$ per tree) $\left(\mathrm{LSD}_{0.05}=3.68\right)$.

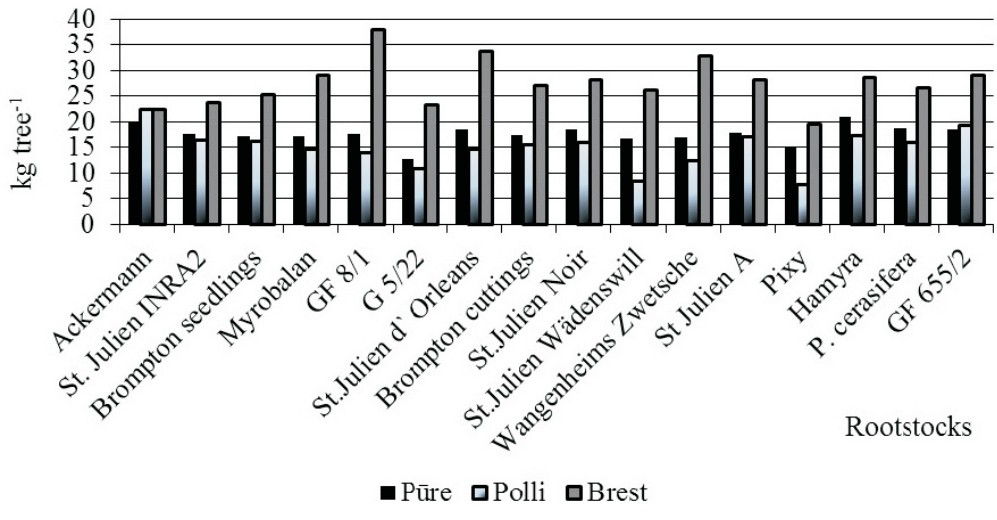

Fig. 2. Average yield during the period of 2008-2015 for cultivar 'Victoria' ( $\mathrm{kg}$ per tree) $(\mathrm{LSD}=5.21)$. 
yield was harvested also from trees grafted on GF $655 / 2$ (37.6 $\mathrm{kg}$ per tree). The lowest average yield was harvested from trees grafted on 'Pixy' (7.7 kg per tree), which can be explained by low tree height (Grzyb and Sitarek, 1998). These trees should be planted in high density and watering is desirable, but irrigation was no employed at Pūre and Polli.

At Brest, the highest average yield for 'Victoria' was harvested from trees grafted on 'GF 8/1', which however did not show similarly good results at Pūre and Polli. 'Victoria' grafted on 'GF 8/1' had low tree survival and thereby the yield per plot was low (Dēķena and Alsiņa, 2011). High average yield was observed also for trees on rootstocks 'St. Julien d' Orleans' (33.8 kg per tree) and 'Wangenheims Zwetsche' (32.8 kg per tree). 'Wangenheims Zwestche' showed good results also in other investigations (Grzyb and Sitarek, 2007). The lowest average yield was harvested from trees grafted on 'Pixy' (19.6 kg per tree), as that observed at Polli.

In general, cultivar 'Kubanskaya Kometa' had the highest yield when grafted on GF 8/1 and 'St. Julien Inra 2' rootstocks in all three growing regions evaluated. In contrast, 'St. Julien A' and P. cerasifera var. divaricata were the least suitable rootstocks for this cultivar. Cultivar 'Victoria' was the most productive grown on rootstocks 'St. Julien d' Orleans' and 'Wangenheims Zwetsche'. The lowest yield was obtained from trees grafted on 'G5/22' and 'Pixy'.

\section{REFERENCES}

Dēkena, Dz., Alsina, I. (2011). Influence of rootstock on wintering and health status of plum cultivar 'Victoria'. In: Research for Rural Development 2011, Annual 17th International Scientific Confernce Proceedings. Latvia University of Agriculture, Jelgava, pp. 47-51.

Dēḳena Dz., Janes, H., Poukh, A., Alsiṇa, I. (2013). Influence of rootstock on plum flowering intensity in different grooving regions. Proc. Latvian Scad. Sci., Section B, 67 (2), 207-210.

Eremin, G. (1993). Breeding for Winterhardiness of Fruit and Berries Plants [Селекиия на зимостойкость плодовых и ягодных культур]. Moscow, pp. 48-54 (in Russian).

Eremin, G., Safarov, P. (2013) Intensive Technologies for Growing of Russian Plum [Интенсивные технологии воздельввания сливы Русской]. Krimsk. 35 pp. (in Russian).
Grāvìte, I., Kaufmane, E. (2013). Results of the comparision of cultivars (P. domestica L.) grafted on Wangenheim prune seedlings [Mājas plūmju (P. domestica L.) škirnu salīdzināšanas rezultāti uz Vangenheima cvečes sēklaudžu potcelmiem]. In: Zinātniski praktiskā konference "Lauksaimniecības zinātne veiksmīgai saimniekošanai”, 21.-22. februārī 2013, Jelgava. Latvia University of Agriculture, Jelgava, pp. 122-125 (in Latvian).

Grzyb, Z. S., Sitarek, M. (2007). Preliminary results on influence of seedling and clonal rootstocks on tree growth and yield of plum cultivars. Acta Hort., 732, 267-270.

Grzyb, Z. S., Sitarek, M., Kozinski, B. (1998). Effect of different rootstocks on growth, yield and fruit quality of four plum cultivars (in Central Poland). Acta Hort., 478, 239-242.

Jänes, H., Kahu, K. (2008). Winter injuries of plum cultivars in winters 2005-2007 in Estonia. In: Proceedings of International Scientific Conference "Sustainable Fruit Growing: From Plant to Product", 28-31 May 2008, Jūrmala, Dobele, Latvia. Latvia State Institute of Fruit Growing, Dobele, pp. 149-153.

Kaufmane, E., Skrivele, M., Rubauskis, E., Ikase, L. (2007). The yield and fruit quality of two plum cultivars on different rootstocks. Sodininkuste ir Darzininkuste, 29 (3), 10-15.

Kaufmane, E., Rubauskis, E., Skrivele M. (2007). Influence of different rootstocks on the growth and yield of plum cultivars. Acta Hort., 734, 387-391.

Lepsis, J., Dēķena, Dz., Dēķens, V. (2008). Evalution of European plum rootstocks in Latvia. In: Proceedings of International Scientific Conference "Sustainable Fruit Growing: From Plant to Product", 28-31 May 2008, Jūrmala, Dobele, Latvia. Latvia State Institute of Fruit Growing, Dobele, pp.77-82.

Lepsis, J., Drudze, I., Dekens, U. (2004). The evaluation of different plum and pear rootstocks in the nursery. Acta Hort., 658, 167-171.

Poukh, E. V., Matveyev, V. A. (2011). Growth vigour and productiveness of 'Victoria' plum cultivar on clonal and seedling rootstocks [Сила роста и продуктивность сорта сливы домашней Виктория на клоновых и семенных подвоях]. Fruit-Growing [Плодоводство], 23, 150-156 (in Russian).

Proebsting, E. L. (1982). Cold Resistance of Stone Fruit Flower Buds. Issued by cooperative extension of Washington State University. 7 pp.

Rozpara, E., Grzyb, Z. (2007). Growth, yield and fruit quality of eighteen plum cultivars grafted on two rootstocks. Acta Hort., 734, 157-161.

Rozpara, E., Glowacka A., Grzyb Z. S. (2010). The growth and yields of plum cultivars grafted on two rootstocks in central Poland. Acta Hort., 874, 255-259.

Sosna, I. (2002). Growth and cropping of four plum cultivars on different rootstocks in South Western Poland. J. Fruit Ornam. Plant Res., 10, 95-103.

Wertheim, S. J. (1998). European plum. Rootstock Guide. Fruit research station Wilhelminadorp, The Netherlands. 144 pp.

Received 21 August 2016

Accepted in the final form 26 May 2017

\section{POTCELMU IETEKME UZ PLŪMJU PRODUKTIVITĀTI DAŽĀDOS AUDZĒŠSNAS REĢIONOS}

Viens no svarīgākajiem priekšnoteikumiem augstas plūmju ražas ieguvei intensīvos augḷu dārzos ir pareiza potcelmu izvēle atbilstoši audzēšanas reğionam un klimatiskajiem apstākḷiem. Pētijjuma mērkis bija novērtēt dažādu potcelmu ietekmi uz divu plūmju šķirṇu: 'Kubanskaja Kometa' (P. rossica. Erem.) un 'Viktorija' (P. domestica L.) produktivitāti dažādos klimatiskos apstākḷos. Tika izmantoti 16 Eiropā pazīstami potcelmi: astoṇi veğetatīvi vairotie ('St. Julien A', 'Brompton', 'Ackermann', 'Pixy', 'GF 8/1', 'G 5/22', 'GF 655/2', 'Hamyra') un astoni ǵeneratīvi vairotie ('St. Julien INRA2', 'St. Julien d'Orleans', 'St. Julien Noir', 'Brompton', 'Wangenheims Zwetsche', 'St. Julien Wädenswil', 'Myrobalan', P. cerasifera var. divaricata). Vērtējums tika veikts eksperimentālos augḷu dārzos, kas ierīkoti Latvijā, Igaunijā un Baltkrievijā 2001. gada pavasarī. Koki stādīti pēc shēmas $3 \times 5$ m četros atkārtojumos, pa trīs kokiem katrā lauciņā. Ir prezentēti apkopoti dati par 2008. līdz 2014. gadu. Potcelmu ietekme uz ražu bija atškirīga gan pa gadiem, gan audzēšanas reǵioniem, gan škirnēm. Ražas lielumu kokiem uz visiem vērtētiem potcelmiem ietekmēja meteoroloğiskie apstākḷi ziemošanas periodā. 